Jurnal Akuntansi \& Perpajakan, Volume 2, No. 1, Juli 2020

\title{
PENGARUH PROFITABILITAS, LIKUIDITAS, STRUKTUR ASET DAN UKURAN PERUSAHAAN TERHADAP STRUKTUR MODAL
}

\author{
Titi Aslah \\ Sekolah Tinggi Ilmu Ekonomi Jayakarta, Jakarta
}

\begin{abstract}
This study aims to examine the effect of profitability, liquidity, asset structure, and company size on the capital structure of mining companies in the Indonesia Stock Exchange, in order to facilitate investors in investing.

The research method used is a quantitative method using secondary data. The population in this study are coal mining companies listed on the Indonesia Stock Exchange from 20132017. The sample used was 18 companies using purposive sampling method, descriptive statistical data analysis techniques using Eviews Software.

The results of this study indicate that profitability has no significant effect on capital structure, which is caused by the inability of the company to produce the maximum length of funds provided by shareholders, which means the company's financial performance is not good. Liquidity has a negative and significant effect on capital structure, where companies have abundant sources of funds, so companies are more likely to use internal funds to finance their investments. Asset structure has no positive effect but is not significant on capital structure, which means the higher the asset structure of a company the lower the company's ability to be able to guarantee long-term debt. The size of the company has a negative and significant effect on capital structure, which means that the larger the company, the greater the funds that will be issued both from their own capital and debt to maintain or develop the company.
\end{abstract}

Keywords: Profitability, Liquidity, Asset Structure, Company Size and Capital Structure

\begin{abstract}
ABSTRAK
Penelitian ini bertujuan untuk menguji pengaruh profitabilitas, likuiditas, struktur asset, dan ukuran perusahaan terhadap struktur modal perusahaan pertambangan di Bursa Efek Indonesia, dalam rangka memfasilitasi investor dalam berinvestasi. Metode penelitian yang digunakan adalah metode kuantitatif dengan menggunakan data sekunder. Populasi dalam penelitian ini adalah perusahaan pertambangan batubara yang terdaftar di Bursa Efek Indonesia dari tahun 2013-2017. Sampel yang digunakan adalah 18 perusahaan dengan menggunakan metode purposive sampling, teknik analisis data statistic deskriptif dengan menggunakan Software Eviews. Hasil dari penelitian ini menunjukkan bahwa profitabilitas tidak berpengaruh signifikan terhadap struktur modal, yang disebabkan oleh tidak mampunya perusahaan dalam menghasilkan laba secara maksimal dari dana yang telah diberikan oleh pemegang saham, yang berarti kinerja keuangan perusahaan kurang baik. Likuiditas berpengaruh negatif dan signifikan terhadap struktur modal, dimana perusahaan memiliki sumber dana yang melimpah, sehingga perusahaan lebih cenderung menggunakan dana internalnya untuk membiayai investasinya. Struktur asset tidak berpengaruh positif namun tidak signifikan terhadap struktur modal, yang berarti semakin tinggi struktur asset perusahaan semakin rendah kemampuan perusahaan untuk dapat menjamin hutang jangka panjang. Ukuran perusahaan berpengaruh negatif dan signifikan terhadap struktur modal, yang berarti semakin besar perusahaan maka semakin besar pula
\end{abstract}


Jurnal Akuntansi \& Perpajakan, Volume 2, No. 1, Juli 2020

dana yang akan dikeluarkan baik dari modal sendiri maupun hutang untuk mempertahankan atau mengembangkan perusahaan.

Kata-kata Kunci: Profitabilitas, Likuiditas, Struktur Aset, Ukuran Perusahaan, dan Struktur Modal

Korespondensi: Titi Aslah, SE., M.Ak. Sekolah Tinggi Ilmu Ekonomi Jayakarta. Jl. Salemba I No. 8- 10, Kel. Kenari, Kec. Senen, Jakarta Pusat, 10430.

Email: titiaslah06@gmail.com

\section{PENDAHULUAN}

Indonesia merupakan negara yang kaya akan sumber daya alam, salah satunya adalah hasil tambang berupa batubara, minyak bumi, timah, gas alam. Batubara sebagai salah satu sumber energi yang melimpah memberikan sumbangsih yang cukup besar dalam menggerakkan roda perekonomian di tanah air, sekaligus sebagai salah satu penopang pembangunan negara. Potensi ini merangsang dunia usaha untuk mengeksplorasi pertambangan sumber daya alam tersebut. Hal tersebut berdampak semakin bergairahnya dunia usaha untuk mendirikan perusahaan yang bergerak dalam bidang pertambangan khususnya batu bara. Dimana tujuan perusahaan adalah untuk memaksimalkan kekayaan atau nilai perusahaan bagi para pemegang saham (Wijaya, 2017:1). Dalam meningkatkan harga pasar saham dengan cara mengukur kinerja operasi perusahaan yang memadukan perhitungan perusahaan dalam rangka menghasilkan laba tanpa mengabaikan kepentingan pemilik perusahaan dan pemangku kepentingan (stakeholders).

Pada penghujung 2018, saham sektor pertambangan masih mengalami penurunan $4.67 \%$ secara month to date $(m t d)$. Walapun penurunan ini terjadi, masih ada beberapa emiten saham pertambangan masuk ke dalam return tertinggi. Seperti PT Kaltim Prima Coal Tbk (ZINC) 10.42\%, PT Aneka Tambang Tbk (ANTM) $7.25 \%$ dan PT Bayan Resources Tbk (BYAN) 0.77\% mengalami kenaikan (amp.kontan.co.id). Awal 2019, harga batubara di pelabuhan Newcastle yang merupakan harga patokan dunia mengalami kenaikan sebesar $1.01 \%$ ke posisi US\$ 99.7/metrik ton, yang ditutup pada $0.139 \%$. harga batubara dunia yang menguat berefek pada harga saham emitenemiten pada sektor tambang batubara di Indonesia. Seiring dengan penguatan harga batubara dunia. Contohnya saham PT Indika Energy Tak (INDY) mencatat 
Jurnal Akuntansi \& Perpajakan, Volume 2, No. 1, Juli 2020

penguatan terbesar $8.01 \%$ di level $\mathrm{Rp}$. 2.090/saham dengan nilai transaksi Rp. 145.13 Milliar. Perusahaan ini fokus pada bisnis batubara melalui anak usahanya PT Kideco Jaya Agung. Beberapa perusahaan batubara yang lain juga mengalami kenaikan, seperti PT Bumi Resources Tbk (BUMI) yang merupaka saham dari Grup Bakrie, saham naik $6.29 \%$ di level Rp 169/saham dengan nilai transaksi Rp 64.59 miliar (www.cnbcindonesia.com).

Hal tersebut diatas menunjukkan bahwa kemampuan perusahaan dalam menghasilkan keuntungan baik laba investasi, pendapatan per saham dan laba penjualan mengalami kenaikan dan penurunan yang dapat mempengaruhi struktur modal dari perusahaan-perusahaan tambang batubara. Salah satu rasio yang biasa digunakan dalam mengukur tingkat kesehatan perusahaan adalah rasio profitabilitas yang dapat diukur dengan return of equity (ROE).

Terjadinya penguatan harga saham batubara juga diikuti oleh kemampuan dalam pembayaran cicilan utang seperti salah satu perusahaan batubara yang dimiliki oleh grup Bakrie yaitu PT. Bumi Resources Tbk. (BUMI), sesuai dengan siaran pers Direktur Bumi Resources, dimana perusahaan ini mampu mencicil utang sebesar US\$ 19.85 Juta atau sekitar
Rp. 281.11 miliar. Pembayaran tersebut termasuk bunga akrual dan bunga yang belum dibayar (back interest) (https://katadata.co.id).

Sansoethan dan Suryono (2016), semakin banyak asset suatu perusahaan berarti semakin banyak collateral assets untuk bisa mendapatkan sumber dana eksternal berupa hutang. Dengan bertambahnya struktur asset maka struktur modal perusahaan yang berasal dari hutang dapat berkemungkinan meningkat. Contohnya, beberapa asset perusahaan batubara yang meningkat sepanjang tahun 2019 ini, seperti PT Bukti Asam Tbk (PTBA). Total asset PTBA menjadi Rp. 24.17 triliun naik $9.91 \%$ dari periode sebelumnya yaitu Rp. 21.99 triliun. Selain PTBA, jumlah asset milik PT Adaro Energy Tbk (ADRO) juga mengalami peningkatan, tercatat jumlah asset sebanyak US\$ 7.06 miliar meningkatkan $3.82 \%$ dari tahun sebelumnya sebanyak US\$ 6.81 miliar (Tijow dkk., 2018; Kontan.co.id).

Besar kecilnya ukuran perusahaan akan berpengaruh pada stuktur modal dengan didasarkan pada kenyataan bahwa pada perusahaan besar dapat membiayai investasinya dengan mudah lewat pasar modal karena mempunyai tingkat pertumbuhan penjualan yang tinggi dan kecilnya kemungkinan informasi asimetris 
Jurnal Akuntansi \& Perpajakan, Volume 2, No. 1, Juli 2020

terjadi di perusahaan ini. Jumlah cadangan batubara menjadi salah satu ukuran prospek bisnis emiten batubara. PT Bumi Resources Tbk (BUMI) masih menjadi perusahaan tambang batubara yang terbesar dilihat dari sisi total cadangan batubara. BUMI memiliki total cadangan sekitar 14 milliar ton batubara atau senilai US\$ 1.3 triliun dengan asumsi harga batubara US4 90 per ton. Diikuti dengan adanya pinjaman jangka panjang BUMI kuartal III-2017 tercatat sebanyak US\$ 1.68 miliar (https://investasi.kontan.co.id).

\section{KAJIAN LITERATUR}

\section{Pengertian Struktur Modal}

Struktur modal merupakan masalah yang penting bagi perusahaan karena baik buruknya struktur modal akan mempunyai efek langsung terhadap posisi finansial perusahaan. Tidak ada ukuran yang pasti mengenai jumlah dan komposisi modal dari tiap-tiap perusahaan, tetapi pada dasarnya pengaturan terhadap struktur modal dalam perusahaan harus berorientasi pada tercapainya stabilitas finansial dan terjaminnya kelangsungan hidup perusahaan.

Menurut Munawir (2014:19) modal adalah hak atau bagian modal, kekayaan perusahaan yang terdiri atas kekayaan yang disetor atau yang berasal dari luar perusahaan dan kekayaan itu hasil aktivitas usaha itu sendiri.

Bringham dan Houston (2011:5) menyatakan struktur modal merupakan perimbangan jumlah utang jangka pendek yang bersifat permanen, utang jangka panjang, saham preferen dan saham biasa.Fahmi (2014:175) Struktur modal merupakan gambaran dari bentuk proporsi finansial perusahaan yaitu antara modal yang dimiliki yang bersumber dari hutang jangka panjang (long term leabilities) dan modal sendiri (share holders equity) yang menjadi sumber pembiayaan dari suatu perusahaan.

\section{Komponen Struktur Modal}

Riyanto (2011:238) struktur modal terdiri dari 2 (dua) komponen, yaitu: (1) Modal Asing (2) Modal Sendiri.

\section{Rasio Struktur Modal (Capital Structure Ratio)}

Untuk dapat memperoleh gambaran tentang perkembangan finansial suatu perusahaan, perlu mengadakan analisa atau interprestasi terhadap data finansial dari perusahaan bersangkutan, dimana data finansial itu tercermin didalam laporan keuangan. Sjahrial dan Purba (2013:37) rasio struktur modal terdiri dari:

1. Rasio Total Utang Terhadap Total Asset (Total Debt to Total Assets Ratio/DAR) 
Jurnal Akuntansi \& Perpajakan, Volume 2, No. 1, Juli 2020

Rasio ini digunakan untuk mengukur seberapa besar jumlah asset perusahaan dibiayai dengan utang. Semakin tinggi rasio ini berarti semakin besar jumlah modal pinjaman yang digunakan untuk investasi pada asset guna menghasilkan keuntungan bagi perusahaan.

$$
D A R=\frac{\text { Total Utang }}{\text { Total Aset }} \times 100 \%
$$

2. Rasio Total Utang Terhadap Modal (Total Debt to Equity Ratio/DER)

Rasio ini digunakan untuk mengukur perimbangan antara kewajiban yang dimiliki perusahaan dengan modal sendiri. Rasio ini juga dapat berati sebagai kemampuan perusahaan dalam memenuhi kewajiban membayarutangnya dengan jaminan modal sendiri.

$$
\text { DER }=\frac{\text { Total Utang }}{\text { Total Ekuitas }} \times 100 \%
$$

3. Rasio Utang Jangka Panjang Terhadap Modal (Long Term Debt to Equity Ratio/LTDER)

Rasio ini digunakan untuk menunjukkan hubungan antara jumlah pinjaman jangka panjang yang diberikan kreditur dengan jumlah modal sendiri yang diberikan oleh pemilik perusahaan. Rasio ini juga digunakan untuk mengukur seberapa besar perbandingan antara utang jangka panjang dengan modal sendiri atau seberapa besar utang jangka panjang dijamin oleh modal sendiri.

$$
\begin{aligned}
\text { LTDER }=\frac{\text { Total Utang Jangka Panjang }}{\text { Total Ekuitas }} \\
\times 100 \%(2.3)
\end{aligned}
$$

\section{Faktor-faktor yang Mempengaruhi Struktur Modal}

Faktor-faktor yang mempengaruhi struktur modal, yang dapat diuraikan antara lain:

\section{Profitabilitas}

Menurut pecking order theory pada umumnya perusahaan-perusahaan yang memiliki tingkat keuntungan tinggi menggunakan hutang relatif kecil. Tingkat keuntungan yang tinggi memingkinkan perusahaan untuk memperoleh sebagian besar pendanaan dari laba ditahan. Meniurut Sartono (2010:58), Profitabilitas adalah kemampuan perusahaan memperoleh laba dalam hubungannya dengan penjualan, total asset maupun modal sendiri. Rasio profitabilitas merupakan rasio yang digunakan untuk menilai kemampuan perusahaan dalam mencari keuntungan.

\section{Likuiditas}

Fahmi (2014:69) menyatakan likuiditas adalah kemampuan suatu perusahaan memenuhi kewajiban jangka pendeknya secara tepat waktu. Likuiditas 
Jurnal Akuntansi \& Perpajakan, Volume 2, No. 1, Juli 2020

adalah kemampuan seseorang atau perusahaan untuk memenuhi kewajiban atau utang yang segera harus dibayar dengan harta lancarnya.

Menurut Munawir (2007:71) jika dilihat dari rasio likuiditas, suatu perusahaan dikatakan mempunyai posisi keuangan yang kuat apabila mampu: (1). Memenuhi kewajibankewajiban tepat pada waktunya (kewajiban keuangan terhadap pihak ekstern). (2). Memelihara modal kerja yang cukup untuk operasi yang normal (kewajiban keuangan terhadap pihak ekstern). (3). Membayar bunga dan deviden yang dibutuhkan. (4). Memelihara tingkat kredit yang menguntungkan.

\section{Struktur Aset}

Struktur asset (assets tangibility) adalah perimbangan atau perbandingan antara asset tetap dengan total asset. Asset terdiri dari asset tetap, asset tak berwujud, asset lancar, dan asset tidak lancar. Asset tetap adalah kekayaan yang dimiliki perusahaan yang secara fisik tampak dan turut berperan dalam operasi perusahaan secara permanen, selain itu mempunyai umur ekonomis lebih dari satu periode dalam kegiatan perusahaan seperti tanah, gedung, mesin, peralatan kantor, kendaraan.

Menurut Brigham dan Houston (2011:175) struktur asset adalah perimbangan atau perbandingan antara asset tetap dan total asset.

\section{Ukuran Perusahaan}

Riyanto (2011:279) menyebutkan bahwa besarnya suatu perusahaan juga mempengaruhi struktur modal perusahaan. Ukuran perusahaan dapat juga mempengaruhi struktur modal karena semakin besar suatu perusahaan akan cenderung menggunakan utang yang lebih besar.

Perusahaan yang besar akan lebih aman dalam memperoleh hutang karena perusahaan mampu dalam pemenuhan kewajibanya dengan adanya diversifikasi yang lebih luas dan memiliki arus kas yang stabil, dan hal ini berarti struktur modalnya juga akan meningkat.

Brigham dan Houston (2011:117) menyebutkan ukuran perusahaan adalah rata-rata total penjualan bersih untuk tahun yang bersangkutan sampai beberapa tahun kemudian. Dalam ini penjualan lebih besar daripada biaya variabel dan biaya tetap, maka akan diperolehjumlah pendapatan sebelum pajak. Sebaliknya, jika penjualan lebih kecil daripada biaya variabel dan tetap maka perusahaan akan menderita kerugian.Halim (2007:93),semakin besar ukuran suatu perusahaan, maka kecenderungan menggunakan modal asing juga akan semakin besar. Hal ini 
Jurnal Akuntansi \& Perpajakan, Volume 2, No. 1, Juli 2020

disebabkan karena perusahaan besar membutuhkan dana yang besar pula untuk menunjang operasionalnya dan salah satu alternatif pemenuhannya adalah dengan modal asing apabila modal sendiri tidak mencukupi.

Dari referensi-referensi diatas dapat disimpulkan bahwa besar kecilnya ukuran perusahaan akan berpengaruh pada struktur modal dengan didasarkan pada kenyataan bahwa pada perusahaan besardapat membiayai investasinya dengan mudah lewat pasar modal karena mempunyai tingkat pertumbuhan penjualan yang tinggi dan kecilnya informasi asimetris terjadi.

\section{Hubungan Antar Variabel Penelitian} Hubungan Profitabilitas $\left(\mathbf{X}_{1}\right)$ Terhadap Struktur Modal (Y)

Profitabilitas merupakan kemampuan perusahaan menghasilkan laba pada tingkat penjualan tertentu dan di periode tertentu. Perusahaan yang memiliki profitabilitas tinggi, akan menghasilkan laba ditahan yang tinggi pula untuk perusahaan. Sesuai dengan pecking order theory yang telah dipaparkan, perusahaan cenderung akan memprioritaskan untuk menggunakan dana internal lalu selanjutnya dana eksternal. Penelitian yang dilakukan oleh Riski Ayu dan Topo Wijono (2017), Dwi Retno (2013) variabel profitabilitas berpengaruh terhadap struktur modal.

\section{Hubungan Likuiditas $\left(\mathrm{X}_{2}\right)$ Terhadap Struktur Modal (Y)}

Likuiditas merupakan gambaran mengenai kemampuan perusahaan untuk membayar segala hutang jangka pendek dengan menggunakan asset lancar yang dimiliki oleh perusahaan. Berdasarkan pecking order theory, perusahaan yang memiliki tingkat likuiditas yang tinggi cenderung tidak menggunakan pembiayaan dari hutang.

\section{Hubungan Struktur Asset $\left(\mathrm{X}_{3}\right)$ Terhadap} Struktur Modal (Y)

Riyanto (2011) menyatakan bahwa semakin tinggi rasio struktur asset (semakin besar jumlah asset tetap) maka perusahaan pun akan memiliki jaminan kemampuan yang lebih besar dalam melakukan pendanaan eksternal yang berarti berpotensi meningkatkan leverage perusahaan. Semakin baik pertumbuhan asset, semakin meningkat juga kepercayan investor terhadap perusahaan.

Hubungan Ukuran Perusahaan $\left(\mathrm{X}_{4}\right)$ Terhadap Struktur Modal (Y)

Ukuran perusahaan menggambarkan besar atau kecilnya sebuah perusahaan. Perusahaan yang besar cenderung akan mudah mendapatkan dana dari pihak eksternal. Hal ini disebabkan karena 
Jurnal Akuntansi \& Perpajakan, Volume 2, No. 1, Juli 2020

perusahaan besar memiliki reputasi yang cukup baik di mata masyarakat.

\section{METODE PENELITIAN}

Penelitian ini bertujuan untuk mengetahui hubungan (korelasi) sebab akibat antara 2 variabel atau lebih yaitu variabel independen atau bebas terhadap variabel dependen atau terikat (Sugiyono 2016:39). Sedangkan berdasarkan jenis datanya, penelitian ini dikategorikan sebagai penelitian kuantitatif kausalitas yaitu penelitian untuk menggambarkan keadaan perusahaan yang dilakukan dengan analisis berdasarkan data yang di dapatkan Variabel dependen dalam penelitian ini adalah struktur modal, sedangkan variabel independennya adalah Profitabilitas, Likuiditas, Struktur Asset dan Ukuran Perusahaan.

Populasi dalam penelitian ini adalah 40 perusahaan pertambangan batubara yang telah terdaftar di BEI mulai tahun 20132017. Populasi adalah wilayah generalisasi yang terdiri atas obyek / subyek yang mempunyai kualitas dan karakteristik tertentu yang ditetapkan oleh peneliti untuk dipelajari dan kemudian ditarik kesimpulannya, (Sugiyono, 2016:80). Sampel yang digunakan dalam penelitian ini adalah perusahaan pertambangan yang terdaftar di Bursa Efek Indonesia dengan jumlah 18 perusahaan. Metode pengambilan sampel yang digunakan adalah purposive sampling, yaitu teknik penentuan sampel dengan pertimbangan tertentu (Sugiyono,2016:85) dimana pengambilan sampel perusahaan dilakukan berdasarkan kriteria.

Data yang digunakan dalam penelitian ini adalah data sekunder yaitu data yang telah dikumpulkan oleh para peneliti, data yang diterbitkan dalam jurnal statistik dan lainnya, serta informasi yang tersedia dari sumber publikasi ataunonpublikasi yang berasal dari dalam atau luar organisasi. Data sekunder juga merupakan sumber data penelitian yang diperoleh peneliti secara tidak langsung melalui media perantara (diperoleh dan dicatat oleh pihak lain). Data sekunder umumnya berupa bukti, catatan atau laporan historis yang telah tersusun dalam arsip (data dokumenter) yang dipublikasikan dan yang tidak dipublikasikan.

Teknik analisis data yang digunakan dalam penelitian ini menggunakan analisis kuantitatif dengan teknik perhitungan statistik. Teknik analisis data meliputi statistik deskriptif, uji asumsi klasik yang meliputi uji normalitas, heteroskedastisitas, autokorelasi, dan multikolinearitas yang bertujuan untuk 
Jurnal Akuntansi \& Perpajakan, Volume 2, No. 1, Juli 2020

memeriksa ketepatan model agar tidak bias dan efisien, uji model, analisis regresi data panel, dan uji hipotesis. Analisis data yang diperoleh dalam penelitian ini akan menggunakan program pengolah data statistik yang dikenal dengan Software Eviews Versi 10. Metode yang digunakan adalah sebagai berikut: (1). Statistik deskriptif, (2). Uji asumsi klasik, (3). Uji heteroskedastisitas,

(4).

Uji

Multikolinearitas, (5). Uji Korelasi.

\section{HASIL DAN PEMBAHASAN}

Dalam bab ini analisis Pengaruh Profitabilitas, Likuiditas, Struktur Asset dan Ukuran Perusahaan Terhadap Struktur Modal. Penelitian ini menggunakan sampel perusahaan Pertambangan di Bursa Efek Indonesia Tahun 2013-2017 sebanyak 18 perusahaan. Berikut adalah nama-nama perusahaan yang dipilih menjadi obyek penelitian:

Tabel Data Nama Perusahaan Sampel

\begin{tabular}{cll}
\hline No. & $\begin{array}{c}\text { Kode } \\
\text { Perusahaan }\end{array}$ & \begin{tabular}{c}
\multicolumn{1}{c}{ Nama } \\
Perusahaan
\end{tabular} \\
\hline 1 & ADRO & $\begin{array}{l}\text { Adaro Energi } \\
\text { Tbk. }\end{array}$ \\
\hline 2 & ARII & $\begin{array}{l}\text { Atlas Resources } \\
\text { Tbk }\end{array}$ \\
\hline 3 & ATPK & $\begin{array}{l}\text { Bara Jaya } \\
\text { Internasional Tbk }\end{array}$ \\
\hline 4 & BSSR & $\begin{array}{l}\text { Baramulti } \\
\text { Suksessarana } \\
\text { Tbk }\end{array}$ \\
\hline
\end{tabular}

\begin{tabular}{|c|c|c|}
\hline 5 & BYAN & $\begin{array}{l}\text { Bayan Resources } \\
\text { Tbk }\end{array}$ \\
\hline 6 & DEWA & $\begin{array}{l}\text { Darma Henwa } \\
\text { Tbk }\end{array}$ \\
\hline 7 & DOID & $\begin{array}{l}\text { Delta Dunia } \\
\text { Makmur Tbk }\end{array}$ \\
\hline 8 & FIRE & $\begin{array}{l}\text { Alfa Energi } \\
\text { Investama Tbk }\end{array}$ \\
\hline 9 & GEMS & $\begin{array}{l}\text { Golden Energi } \\
\text { Mines Tbk }\end{array}$ \\
\hline 10 & GTBO & $\begin{array}{l}\text { Garda Tujuh } \\
\text { Buana Tbk }\end{array}$ \\
\hline 11 & HRUM & $\begin{array}{l}\text { Harum Energi } \\
\text { Tbk }\end{array}$ \\
\hline 12 & ITMG & $\begin{array}{l}\text { Indo Tambang } \\
\text { Raya Megah Tbk }\end{array}$ \\
\hline 13 & KKGI & $\begin{array}{l}\text { Resources Alam } \\
\text { Indonesia Tbk }\end{array}$ \\
\hline 14 & MBAP & $\begin{array}{l}\text { Mitrabara } \\
\text { Adiperdana Tbk }\end{array}$ \\
\hline 15 & PKPK & $\begin{array}{l}\text { Perdana Karya } \\
\text { Perkasa Tbk }\end{array}$ \\
\hline 16 & PTRO & Petrosea Tbk \\
\hline 17 & SMMT & $\begin{array}{l}\text { Golden Eagle } \\
\text { Energi Tbk }\end{array}$ \\
\hline 18 & TOBA & $\begin{array}{l}\text { Toba Bara } \\
\text { Sejahtera Tbk }\end{array}$ \\
\hline
\end{tabular}

Sumber: www.idx.co.id "telah diolah kembali.

\subsection{Statistik Deskriptif}

Statistik deskriptif berkaitan dengan proses pengumpulan, penyajian, dan peringkasan berbagai karakteristik data sehingga dapat menggambarkan karakter sampel yang digunakan dalam penelitian ini. Analisis deskriptif dari data yang diambil untuk penelitian ini adalah dari tahun 2013 sampai dengan tahun 2017 yaitu sebanyak 18 data perusahaan. Deskripsi variabel dalam statistik deskriptif yang 
Jurnal Akuntansi \& Perpajakan, Volume 2, No. 1, Juli 2020

digunakan pada penelitian ini meliputi nilai minimum, nilai maksimum, mean, dan standar deviasi dari satu variabel dependen yaitu struktur modal dan empat variabel independen yaitu profitabilitas, likuiditas, struktur aset, dan ukuran perusahaan.

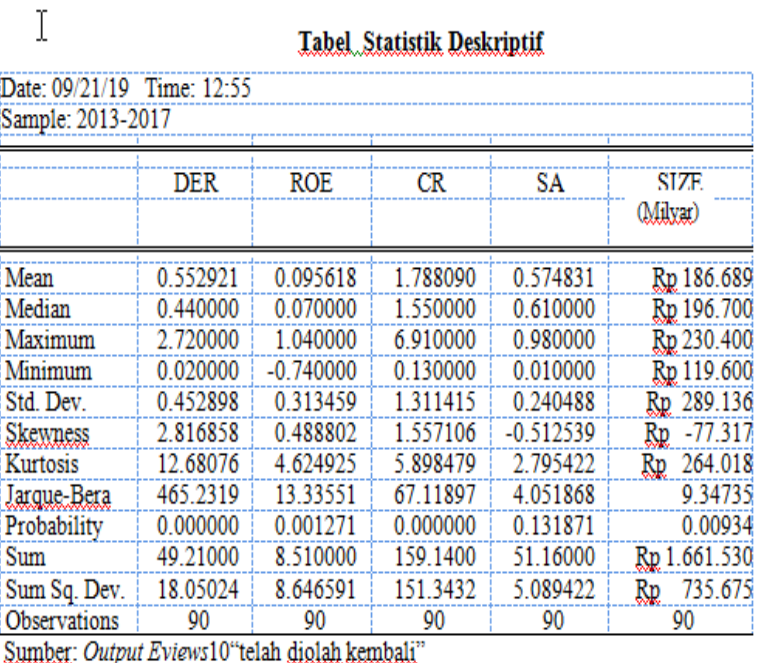

Sumber: Output Eviews10"telah diolah kembali"

\subsection{Uji Asumsi Klasik}

Sesuai dengan tujuan penelitian yang akan dilaksanakan, yaitu untuk mengetahui bagaimana pengaruh profitabilitas, likuiditas, struktur aset, dan ukuran perusahaan terhadap struktur modal, maka sebelum dilakukan analisis data dan pengujian hipotesis maka terlebih dahulu akan dilakukan pengujian terhadap asumsiasumsi dalam analisis regresi yaitu pengujian asumsi klasik yang meliputi:

\section{Uji Heteroskedastisitas}

Uji heteroskedastisitas bertujuan menguji apakah dalam model regresi terjadi ketidaksamaan variance dari residual suatu pengamatan ke pengamatan yang lain. Jika varians dari suatu pengamatan ke pengamatan yang lain sama maka disebut homokedastisitas. Dan jika varians berbeda maka disebut heteroskedastisitas. Model regresi yang baik adalah yang homoskedastisitas atau tidak terjadi heteroskedastisitas (Ghozali, 2013:111). Adapun hasil regresi uji heteroskedastisitas adalah sebagai berikut:

Nilai Probability Likelihood ratio $\mathbf{0 , 0 0 0 0}<\mathbf{0 , 0 5}$ Hasil uji Panel Cross-section Heteroskedasticity LR Test terjadi heteroskedastisitas. Saat terdeteksi adanya heteroskedastisitas, penyembuhan gejala tersebut langsung dilakukan menggunakan menu White cross-section yang tersedia pada aplikasi Eviews.

Dari hasil pengujian, berdasarkan nilai probabilitas untuk masing-masing variabel independen memiliki nilai probabilitas yang lebih besar dari 0,05. Nilai Probability Likelihood ratio 1,0000> 0,05 Hasil uji Panel Period Heteroskedasticity LR Test tersebut tidak terjadi heteroskedastisitas. Hal ini sesuai dengan kriteria pengujian bahwa hasil dari uji heteroskedastisitas memiliki nilai probabilitas antar variabel yang lebih besar dari 0,05. Maka dapat disimpulkan bahwa tidak terjadi heteroskedastisitas. Kecuali variabel $\mathrm{CR}$ memiliki nilai probabilitas 
Jurnal Akuntansi \& Perpajakan, Volume 2, No. 1, Juli 2020

dibawah 0,05 maka variabel ini terjadi heteroskedastisitas.

\section{Uji Multikolinearitas}

Uji multikolinearitas bertujuan untuk mengetahui apakah dalam model regresi ditemukan adanya korelasi antar variabel independen. Dalam penelitian ini, pengujian multikolinearitas menggunakan Pearson Correlation. Kriteria Pearson Correlation untuk uji multikolinearitas adalah jika nilai koefisien korelasinya melebihi 0,8 untuk mendeteksi ada atau tidaknya multikolinearitas.

Berdasarkan hasil pengujian diketahui bahwa nilai koefisien antar variabel lebih kecil dari 0,8. Hal ini sesuai dengan kriteria pengujian bahwa hasil dari uji multikolinearitas tidak ada nilai koefisien korelasi antar variabel yang lebih dari 0,8. Maka dapat disimpulkan bahwa data tidak memiliki masalah multikolinearitas.

\section{Uji Korelasi}

\section{A. Uji Autokorelasi}

Uji autokorelasi dilakukan untuk mengetahui ada tidaknya korelasi antara faktor pengganggu yang satu dengan lainnya (non autocorelation).Untuk menguji ada tidaknya autokorelasi dapat digunakan tes Durbin Watson.

Nilai Probability Breusch-Pagan LM 0,0000< 0,05 Hasil uji Lagrange
Multiplier test (LM) tersebut terjadi autokorelasi. Saat terdeteksi adanya autokorelasi uji LM, penyembuhan segera dilakukan melalui Cross-section weightsyang tersedia pada aplikasi Eviews.

\section{B. Uji Cross Correlation}

Uji ini digunakan apabila didapat kesimpulan bahwa struktur varianskovarians residual bersifat heteroskedastik, maka selanjutnya dilakukan uji LM untuk mengetahui apakah terdapat cross sectional correlation atau tidak pada struktur varianscovarians tersebut.

Diperoleh nilai statistik uji $\lambda \mathrm{LM}=$ $0,0000<0,05$ sehingga struktur variancovarian residual dari model FEM adalah bersifat non-heterokedastik dan tidak terdapat Cross-Sectional Correlation.

\subsection{Model Regresi Data Panel}

Penelitian ini menggunakan metode estimasi model regresi dengan menggunakan data panel. Dapat dilakukan melalui tiga pendekatan, antara lain: (1) Common Effect Model (CEM), (2) Fixed Effect Model (FEM), dan (3) Random Effect Model (REM). Berikut merupakan aplikasi dari ketiga model regresi yang diterapkan dalam penelitian ini:

\section{A. Common Effect Model (CEM) \\ Pada common effect model diasumsikan bahwa tidak ada perbedaan}


Jurnal Akuntansi \& Perpajakan, Volume 2, No. 1, Juli 2020

nilai intersep dan slope pada hasil regresi baik atas dasar perbedaan antar individu maupun antar waktu. Metode pendugaan parameter pada common effect model menggunakan metode Ordinary Least Square (OLS).Hasil regresi data panel dengan Common Effect Model.

Berdasarkan hasil terdapat dua variabel dengan tes individual (t-test probability) terlihat signifikan dengan $\alpha=$ 5\% dan nilai adjusted $\mathrm{R} 2$ sebesar 0,253202. Nilai probability dari $f$-stat senilai 0,000001 memberikan arti bahwa model tersebut significant. Dan nilai Durbin-Watson stat sebesar 0,270893 yang belum mendekati range angka 2.

\section{B. $\quad$ Fixed Effect Model (FEM)}

Metode pendugaan regresi data panel pada Fixed Effect Model menggunakan teknik penambahan variabel dummy atau Least Square Dummy Variabel (LSDV). Hasil regresi data panel dengan Fixed Effect Model.

Hasil dapat dilihat bahwa uji t-stat terdapat dua variabel yang memperlihatkan signifikansi $(\alpha=5 \%)$. Selanjutnya, nilai adjusted R2 yaitu 0,845824. Nilai probability dari $f$-stat senilai 0,000000 memberikan arti bahwa model tersebut signifikan. Serta nilai Durbin-Watson stat sebesar 0,970133 yang belum mendekati range angka 2.

\section{Random Effect Model (REM)}

Random Effect Model diakomodasi lewat error. Metode pendugaan regresi data panel pada Random Effect Model menggunakan metode Generalized Least Square (GLS).

Hasil dapat dilihat bahwa uji $t$-stat terdapat dua variabel yang memperlihatkan signifikansi $(\alpha=5 \%)$. Nilai adjusted R2 yaitu 0,117604 . Nilai probability dari $f$-stat senilai 0,002317 memberikan arti bahwa model tersebut signifikan. Serta nilai Durbin-Watson stat sebesar 0,140979 yang belum mendekati kisaran range angka 2 .

\subsection{Analisis Regresi Data Panel}

Berdasarkan pendekatan model regresi data panel dengan Eviews (Common Effect Model, Fixed Effect Model, dan Random Effect Model) dan uji yang telah dilakukan (Chow Test, Hausman Test, dan Lagrange Multiplier Test) menunjukan bahwa model regresi yang lebih tepat untuk digunakan dalam penelitian ini adalah Fixed Effect Model.

Berdasarkan hasil regresi, maka dapat diperoleh suatu persamaan garis regresi sebagai berikut:

$$
\mathrm{LTDER}_{\mathrm{t}}=3,828078+(-0,024825)
$$

$\mathrm{ROE}_{\mathrm{it}}+(-0,064146) \mathrm{CR}_{\mathrm{it}}+(0,039142) \mathrm{SA}_{\mathrm{it}}$ $+(-0,705853) \mathrm{LN}_{\mathrm{it}}+\varepsilon_{\mathrm{it}}$ 
Jurnal Akuntansi \& Perpajakan, Volume 2, No. 1, Juli 2020

Persamaan di atas dapat

diinterpretasikan sebagai berikut:

1. Konstanta $\alpha$ sebesar 3,828078

menyatakan bahwa jika variabel $\mathrm{X}$ konstan, maka variabel struktur modal adalah 3,828078 .

2. Koefisien regresi ROE sebesar 0,024825 menyatakan bahwa setiap penambahan variabel Profitabilitas sebesar $1 \%$ akan meningkatkan variabel Struktur Modal sebesar 0,024825 dengan asumsi variabel bebas lain besarnya konstan.

3. Koefisien regresi CR sebesar 0,064146 menyatakan bahwa setiap penambahan variabel Likuiditas sebesar $1 \%$ akan menurunkan variabel Struktur Modal sebesar 0,064146 dengan asumsi variabel bebas lain besarnya konstan.

4. Koefisien regresi SA sebesar 0,039142 menyatakan bahwa setiap penambahan variabel Struktur Asset sebesar 1\% akan menurunkan variabel Struktur Modal sebesar 0,039142 dengan asumsi variabel bebas lain besarnya konstan.

5. Koefisien regresi Size sebesar 0,705853 menyatakan bahwa setiap penambahan variabel Size sebesar $1 \%$ akan menurunkan variabel Struktur Modal sebesar -0,705853 dengan asumsi variabel bebas lain besarnya konstan.

\subsection{Pembahasan}

A. Analisis Pengaruh Profitabilitas (ROE) Terhadap Struktur Modal

Hasil pengujian dalam penelitian ini menunjukkan bahwa Profitabilitas (ROE) tidak memiliki pengaruh terhadap Struktur Modal. Hal ini dibutikkan dengan nilai signifikansi $0,3413>0,05$, dengan nilai tstatistic sebesar $-0,957343$, berarti profitabilitas tidak berpengaruh negative dan tidak signifikan terhadap struktur modal. Hal ini konsisten yang dilakukan oleh Kawiswara, et.al (2014), Wulandari (2013),Dewi dan Wirajaya (2013) yang mengatakan bahwa profitabilitas tidak berpengaruh terhadap struktur modal. Hasil pengujiaan menunjukkan bahwa profitabilitas tidak berpengaruh signifikan terhadap struktur modal, berarti apabila profitabilitas meningkat maka struktur modal akan mengalami penurunan dimana dengan menurunnya struktur modal sebagai akibat berkurangnya hutang jangka panjang yang bisa dilunasi dengan profit yang naik.

Penelitian ini berbeda dengan penelitian yang dilakukan oleh Nunky (2013) yang menyatakan bahwa Tidak terdapat pengaruh positif profitabilitas terhadap struktur modal. Hasil penelitian 
Jurnal Akuntansi \& Perpajakan, Volume 2, No. 1, Juli 2020

yang tidak signifikan ini disebabkan oleh tidak mampunya perusahaan dalam menghasilkan laba secara maksimal dari dana yang telah diberikan oleh pemegang saham, yang berarti kinerja keuangan perusahaan kurang baik.

\section{B. Analisis Pengaruh Likuiditas}

\section{(CR) Terhadap Struktur Modal}

Hasil pengujian dalam penelitian ini menunjukkan bahwa Likuiditas (CR) memiliki pengaruh terhadap Struktur Modal. Hal ini dibutikkan dengan nilai signifikansi $0,000<0,05$ dengan nilai tstatistic sebesar $-4,833363$, berarti likuiditas berpengaruh negatif dan signifikan terhdap struktur modal. Hal ini konsisten yang dilakukan oleh Dian \& Suwitho (2015), Sibilkov (2018) yang mengatakan bahwa Likuiditas (CR) berpengaruh terhadap struktur modal. Hal ini dikarenakan tingkat likuiditas yang tinggi justru tingkat hutangnya rendah, sehingga perusahaan tidak menggunakan pembiayaan dari hutang. Dan perusahaan memiliki sumber dana yang melimpah, sehingga perusahaan lebih cenderung menggunakan dana internalnya untuk membiayai investasinya sebelum menggunakan pembiayaan eksternal melalui hutang.

Penelitian ini berbeda dengan penelitian yang dilakukan oleh Wulandari
(2013) yang menyebutkan bahwa Current Ratio berpengaruh negatif dan signifikan terhadap struktur modal. Secara teori, seharusnya $\mathrm{CR}$ yang tinggi mengindikasikan adanya dana yang menganggur, sehingga akan mengurangi tingkat laba atau profitabilitas perusahaan, yang berarti juga menyebabkan struktur modal akan turun.

\section{Analisis Pengaruh Struktur Aset} (SA) Terhadap Struktur Modal

Hasil pengujian dalam penelitian ini menunjukkan bahwa struktur aset (SA) tidak memiliki pengaruh terhadap struktur modal. Hal ini ada dibutikkan dengan nilai signifikansi $0,2214>0,05$ dengan nilai $t-$ statistic sebesar 1,232322, berarti struktur asset tidak berpengaruh positif namun tidak signifikan terhadap struktur modal. Hal ini konsisten yang dilakukan oleh Kawiswara, et.al (2014) mengatakan bahwa struktur aset (SA) tidak berpengaruh terhadap struktur modal. Hasil penelitian ini menunjukkan bahwa semakin tinggi struktur aktiva perusahaaan, menunjukkan semakin rendah kemampuan dari perusahaan tersebut untuk dapat menjamin hutang jangka panjang yang dipinjamnya.

Penelitian ini berbeda dengan penelitian yang dilakukan olehSawitri dan Lestari (2015) yang menyatakan bahwa ukuran perusahaan tidak berpengaruh 
Jurnal Akuntansi \& Perpajakan, Volume 2, No. 1, Juli 2020

signifikan terhadap struktur modal.Menurut

Sitanggang (2013:75) komposisi aktiva tetap berwujud perusahaan yang jumlahnya besar akan mempunyai peluang untuk memperoleh tambahan modal dengan hutang, karena aktiva tetap tersebut dapat dijadikan sebagai jaminan untuk memperoleh hutang.Sehingga ini menunjukkan bahwa perusahaan tidak mampu untuk memperoleh tambahan modal dengan hutang.

\section{Analisis Pengaruh Ukuran Perusahaan (LN) Terhadap Struktur Modal}

Hasil pengujian dalam penelitian ini menunjukkan bahwa ukuran perusahaan (SIZE) memiliki pengaruh negatif dan signifikan terhadap struktur modal. Hal ini dibutikkan dengan nilai signifikansi 0,0000>0,05 dengan nilai t-statistic sebesar -4,583228, berarti ukuran perusahaan berpengaruh negative dan signifikan terhadap struktur modal. Hal ini konsisten yang dilakukan oleh Fatimatus MB \& Suwitho (2016) mengatakan bahwa ukuran perusahaan (SIZE) berpengaruh terhadap struktur modal. Hasil penelitian ini menunjukkan bahwa semakin besar perusahaan maka semakin besar pula dana yang akan dikeluarkan baik dari modal sendiri maupun hutang untuk mempertahankan atau mengembangkan perusahaan.

\section{KESIMPULAN}

Berdasarkan hasil penelitian yang telah dilakukan untuk menganalisis pengaruh profitabilitas, likuiditas, struktur asset, ukuran perusahaan terhadap struktur modal pada perusahaan pertambangan yang terdaftar di BEI periode 2013-2017 dapat disimpulkan sebagai berikut:

1. Hasil pengujian dalam penelitian ini menunjukkan bahwa Profitabilitas (ROE) tidak berpengaruh negatif dan tidak signifikan terhadap struktur modal, yang disebabkan oleh tidak mampunya perusahaan dalam menghasilkan laba secara maksimal dari dana yang telah diberikan oleh pemegang saham. Hal ini berarti kinerja keuangan perusahaan kurang baik.

2. Hasil pengujian dalam penelitian ini menunjukkan bahwa Likuiditas (CR) memiliki pengaruh terhadap struktur modal, dikarenakan tingkat likuiditas yang tinggi justru tingkat hutangnya rendah, sehingga perusahaan tidak menggunakan pembiayaan dari hutang. Hal ini berarti perusahaan memiliki sumber dana yang melimpah, sehingga 
Jurnal Akuntansi \& Perpajakan, Volume 2, No. 1, Juli 2020

perusahaan lebih cederung menggunakan dana internalnya untuk membiayai investasinya.

3. Hasil pengujian dalam penelitian ini menunjukkan bahwa struktur asset (SA) tidak memiliki pengaruh terhadap struktur modal. Hal ini berarti semakin tinggi struktur aset perusahaan semakin rendah kemampuan perusahaan untuk dapat menjamin hutang jangka panjang yang di pinjamnya.

4. Hasil pengujian dalam penelitian ini menunjukkan bahwa ukuran perusahaan (SIZE) memiliki pengaruh negatif dan signifikan terhadap struktur modal. Hal ini berarti semakin besar perusahaan maka semakin besar pula dana yang akan dikeluarkan baik dari modal sendiri maupun hutang untuk mempertahankan atau mengembangkan perusahaan.

\section{REFERENSI}

Abiprayasa, Kawiswara. 2014. Faktor-faktor yang Mempengaruhi Struktur Modal pada Perusahaan Tekstil dan Garmen. Accounting Analysis Journal 3 (2) 247254.

Bambang, Riyanto. 2011. Dasar-Dasar Pembelanjaan Perusahaan. Yogyakarta, BPFE.

Brigham, Eugene F. and Joel F. Houston. 2011. Dasar-dasar Manajemen Keuangan,
Edisi 11, Penerjemah Ali Akbar Yulianto, Jakarta, Salemba Empat.

Dwi Retno Wulandari. 2013. Pengaruh Profitabilitas, Operating Laferage, Likuiditas Terhadap Nilai Perusahaan Dengan Struktur Modal Sebagai Variabel Interfening. Accounting Analysis Journal 3 (1) 455-463.

Fahmi, Irham 2014. Analisa Laporan Keuangan, Yogyakarta, Alfabeta

,2014. Manajemen Keuangan Perusahaan dan Pasar Modal. Jakarta, Mitra Wacana Media.

Ghozali, Imam 2013. Aplikasi Analisis Multivariate dengan program IBM SPSS 21 Update PLS Regresi. Semarang. Badan Penerbit Iniversitas Diponegoro.

Gujarati, Damodar. 2012, Dasar-dasar Ekonometrika ( Mangunsong, R.C : Penerjemah). Jakarta. Salemba Empat

Hanafi \& Abdul. Analisa Laporan Keuangan. Yogyakarta. STIM YKPN.

Kasmir. 2010. Pengantar Manajemen Keuangan. Jakarta. Kencana Media Group.

Kesuma, Ali. 2009. Analisis Faktor yang Mempengaruhi Struktur Modal serta Pengaruhnya Terhadap Harga Saham Perusahaan Real Estate yang Go-Public Di BEI. Jurnal Manajemen \& Kewirausahaan. Vol. II. No. 1: 38-45

Mahapsari, Nungky R. dan Abdullah T. 2013. Pengaruh Profitabilitas, Struktur Aktiva, dan Perrtumbuhan Penjualan Terhadap Harga Saham Dengan Struktur Modal Sebagai Variabel Intervening Pada Perusahaan Manufaktur di Bursa Efek Indonesia. Jurnal Nominal, Vol II No. 1. Yogyakarta: Universitas Negeri Yogyakarta

Munawir. S. 2014. Analisa Laporan Keuangan, Yogyakarta, Liberty.

Putra.2018. Pengaruh Struktur Modal dan Profitabilitas Terhadap Harga Saham, Studi pada sektor pertambangan subsektor batu bara, Institutional repositories \& scientific journals Universitas Pasundan.

Sabir, Mahvish dan Qaisar A.M. 2012.Determinants of Capital Structure A Study of Oil and Gas Sector of Pakistan. Interdisciplinary Journal of 
Jurnal Akuntansi \& Perpajakan, Volume 2, No. 1, Juli 2020

Contemporary Research In Business, 3 (10), pp: 395-400.

Sansoethan, D.K., dan B. Suryono. 2016. Faktor-faktor yang mempengaruhi Struktur Modal pada Perusahaan Makanan dan Minuman. Jurnal Ilmu dan Riset Akuntansi. 5(1):1-20

Sartono. 2010. Manajemen Keuangan Teori dan Aplikasi. Yogyakarta. BPFE

Seftianne, \& Handayani, R. 2011.Faktor-Faktor Yang Mempengaruhi Struktur Modal Pada Perusahaan Publik Sektor Manufaktur. Jurnal Bisnis Dan Akuntansi, 13(1), 39-56.

Siamat Dahlan. 2005. Manajemen Lembaga keuangan. Jakarta. Fakultas Ekonomi UI.

Sjahrial, Dermawan dan Djahotman Purba. 2013. Analisis Laporan Keuangan. Jakarta. Mitra Wacana Media.

Suad Husnan. 2008. Manajemen Keuangan, Teori dan Penerapan. Yogyakarta. BPEF.

Subramanyam.K.R. 2017. Analisa Laporan Keuangan. Jakarta. Salemba Empat

Sudana I Made. 2011. Manajemen Keuangan Teori dan Praktek. Jakarta. Erlangga.

Sugiyono. 2016. Metode Penelitian Kwantitatif, Kwalitatif, dan $R \& D$. Bandung. Alvabeta.

Sutrisno. 2012. Manajemen Keuangan Teori, Konsep dan Aplikasi. Yogyakarta. EKONISIA

Syamsudin Lukman. 2009. Manajemen Keuangan Perusahaan. Jakarta. Raja Grafindo Indonesia.

Tongkong, Supa. 2012. Key factors influencing capital structure decision and its speed of adjusment of thai listed real estate company. Procedia - Social and Behavioral Sciences 40 ( 2012 ) 716 720 .

Vergas, Nelson. Cerqueira, Antonio \& Brandao, Elisio. 2015. The Determinants of The Capital Structure of Listed on Stock Market Nonfinancial Firms : Evidence for Portugal. FEP-UP. School of Economics and Managemen. University of Porto.

Wijaya. 2017. Manajemen Keuanagn Konsep dan Penerapannya. Jakarta. Kompas Gramedia
Wijaya, I Putu Andre Suta \& Utama, I Made Karya. 2014. Pengaruh Profitabilits, Struktur Asset dan Pertumbuhan Penjualan Terhadap Struktur Modal Serta Harga Saham. E-Jurnal Akuntansi Universitas Udayana. Vol 6 No.3.

Yuliana \& Vivi .2015. Pengaruh Resiko Bisnis, Ukuran Perusahaan dan Pertumbuhan Penjualan Terhadap Struktur Modal. EJurnal Manajemen Umut. Vol 4 No.5 1238-1251.

Zuhro, Fatimatus MB, dan Suwitho. 2016. Pengaruh Ukuran Perusahaan, Pertumbuhan Aset Dan Profitabilitas Terhadap Struktur Modal. Jurnal Ilmu dan Riset Manajemen Volume 5. ISSN: 2461-0593.

www.idx.co.id. Diakses pada Juni 2019 